\title{
悪臭規制状況等調査結果
}

紙パルプ技術協会 環境技術委員会

日本製紙連合会 環境保全委員会

\section{Offensive Odor Regulation and the Technologies Used to Clear the Target at Local Pulp Mills in Japan}

Environmental Technical Committee, JAPAN TAPPI

Environmental Protection Committee, Japan Paper Association

37 kraft pulp mills are operating in Japan. The offensive odor emission has been under control of the law since 1972. As local governments can modify the national law, and specify their own limit values for odor emission, depending on their local requirement, a survey was made to know the limit value and the technologies used to clear the target at each mill. The survey covers all kraft pulp mills.

\section{1. 調查対象工場}

KP を製造する 20 社 37 工場に調査票を送付し，全 工場から回答を得た。なお, 本年 3 月に 1 工場が $\mathrm{KP}$ 設備を休転したため, 現在稼働している工場は 36 工 場となっている。

\section{2. 敷地境界線臭気規制実施状況}

（1） 1 号（敷地境界線）規制実施状況について KP 製造工場の敷地境界線における規制（1号規 制）状況について調查した。硫化水素については, 表 1 に示すように 37 工場の内 27 工場が悪臭防止法に基 づく道府県条例或いは告示によって最も厳しい臭気強 度 2.5 の規制を受けている。また，残る 10 工場にお

表 $1 \mathrm{KP}$ 製造工場の悪臭 1 号（敷地境界線）規制実施状況

\begin{tabular}{c|c|c|c|c|c|c|c|c}
\hline \multirow{2}{*}{$\begin{array}{c}\text { 臭気 } \\
\text { 強度 }\end{array}$} & \multicolumn{2}{|c|}{$\begin{array}{c}\text { 硫化水素 } \\
\left(\mathrm{H}_{2} \mathrm{~S}\right)\end{array}$} & \multicolumn{2}{c|}{$\begin{array}{c}\text { メチルルカプタン } \\
(\mathrm{MM})\end{array}$} & \multicolumn{2}{c|}{$\begin{array}{c}\text { 硫化メチル } \\
(\mathrm{DMS})\end{array}$} & \multicolumn{2}{c}{$\begin{array}{c}\text { 二硫化メチル } \\
(\mathrm{DMDS})\end{array}$} \\
\cline { 2 - 10 } & 条例/告示 & 規制值 & 条例/告示 & 規制值 & 条例/告示 & 規制值 & 条例/告示 & 規制值 \\
\hline 2.5 & 27 工場 & 32 工場 & 26 工場 & 30 工場 & 26 工場 & 32 工場 & 28 工場 & 32 工場 \\
\hline 2.8 & 1 & 0 & 1 & 0 & 1 & 0 & 0 & 0 \\
\hline 3.0 & 7 & 3 & 8 & 5 & 8 & 3 & 8 & 4 \\
\hline 3.2 & 0 & 1 & 0 & 1 & 0 & 1 & 0 & 1 \\
\hline 3.5 & 2 & 1 & 2 & 1 & 2 & 1 & 1 & 0 \\
\hline 合計 & 37 & 37 & 37 & 37 & 37 & 37 & 37 & 37 \\
\hline
\end{tabular}

註） 規制值；協定による上乗せ規制を含めて，実際に適用される最も厳しい規制值を示す。 
表 $2 \mathrm{KP}$ 製造工場の徳臭 2 号（排出口）規制実施状況

\begin{tabular}{|c|c|c|c|c|c|c|c|}
\hline & \multicolumn{2}{|c|}{ 着地濃度規制 } & \multicolumn{2}{|c|}{$\begin{array}{c}\text { 排煙（排出口）濃度 } \\
\text { 上乗せ規制 }\end{array}$} & \multicolumn{3}{|c|}{$\begin{array}{c}\text { 排出量（総量）規制 } \\
\text { 上乗せ規制 }\end{array}$} \\
\hline 被規制工場数 & \multicolumn{2}{|c|}{37 工場 } & \multicolumn{2}{|l|}{6 工場 } & \multicolumn{3}{|c|}{3 工場 } \\
\hline 規制基準 & $\begin{array}{ll}\mathrm{H}_{2} \mathrm{~S} & 0.02 \mathrm{ppm} \\
\mathrm{H}_{2} \mathrm{~S} & 0.05 \\
\mathrm{H}_{2} \mathrm{~S} & 0.06 \\
\mathrm{H}_{2} \mathrm{~S} & 0.1\end{array}$ & $\begin{array}{l}32 \text { 工場 } \\
3 \\
1 \\
1\end{array}$ & $\begin{array}{l}\mathrm{H}_{2} \mathrm{~S} \quad 20 \mathrm{ppm} \\
\mathrm{H}_{2} \mathrm{~S} \quad 75 \mathrm{mg} / \mathrm{Nm}^{3}(*) \\
\mathrm{H}_{2} \mathrm{~S} \quad 70 \mathrm{ppm} \\
\mathrm{H}_{2} \mathrm{~S} 217 \mathrm{ppm} \\
\quad \text { (*) } 49 \mathrm{ppm} \text { に相当 }\end{array}$ & $\begin{array}{l}1 \text { 工場 } \\
3 \text { 工場 } \\
1 \\
1\end{array}$ & $\begin{array}{l}\mathrm{H}_{2} \\
\mathrm{H}_{2} \\
\mathrm{H}_{2}\end{array}$ & $\begin{array}{r}30 \mathrm{Nm}^{3} / \text { 日 } \\
50 \mathrm{Nm}^{3} / \text { 日 } \\
11.1 \mathrm{Nm}^{3} \text { 時 }\end{array}$ & $\begin{array}{l}1 \text { 工場 } \\
1 \text { 工場 } \\
1 \text { 工場 }\end{array}$ \\
\hline
\end{tabular}

いても 5 工場が協定によって臭気強度 2.5 の上乗せ規 制を受けており，結果として全体の $86 \%$ に相当する 32 工場が最も厳しい規制を受けている。同様に，硫 化メチルと二硫化メチルについても 32 工場 (86\%)が, またメチルメルカプタンについては 30 工場（81\%） が臭気強度 2.5 の規制を受けている。

(2) 2 号（排出口）規制実施状況について

覀臭防止法の 2 号（排出口）規制に基づき，全工場 が硫化水素について敷地境界線規制の臭気強度に相当 する着地濃度規制を受けており，その内 6 工場が条例 によって排出口排煙濃度の上乗せ規制を受けている。 また，3工場が条例或いは協定によって排出量（総 量）の上乗せ規制を受けている（表 2）。

\section{3. 官能臭気規制状況について}

$\mathrm{KP}$ 工場が立地する自治体で, 指導要綱等で官能臭 気規制を実施している自治体は 1 道 3 県 3 市で, KP 37 工場の内 16 工場 (43\%) が規制を受けている。また, 官能臭気の測定法は, 宮城県が三点比較式臭気採点法 を採用しているのを除いて，他の自治体は全て三点比 較式臭袋法を採用している。規制值超過に対する措置 については，改善勧告或いは改善措置の指導などが規 定されているが，罰則規定は設けられていない。

表 3-1の KP 工場は何れも悪臭防止法に基づく濃 度規制を受けているので, 官能臭気規制は形式的なも のになっているようである。また自治体によっては, 公害防止協定を締結していない小規模な事業場・工場 等を対象にしているところもあるようである。しかし， 公害防止条例ではその対象が畜産や塗装吹付施設等で あって，KP 工場は適用外になっているにも拘らず， 県の官能臭気立入り調查を受け, 規制と同等の取り扱 いを受けている事例が 1 工場から報告されている。因 みに官能試験法を採用している地方自治体を表 3-2に 示す。

一方, 平成 5 年に大竹市が指導要綱を，また岩手県
が指導要領を制定して官能臭気規制を実施し，更に富 士市が規制強化（敷地境界線臭気濃度；現行 $90 \rightarrow 70$ ) を平成 7 年 4 月 1 日から予定しているなど規制強化の 動きも見られる。

また，ガスクロ測定では全く問題なく規制值をクリ アしていても，官能臭気測定では複合臭気を感じるこ とがあるとも言われ, 硫黄系 4 物質以外にも未知の臭 気物質があることも考えられる。原因究明に努めてい く必要があるのではないかと思われる。

尚, 現在環境庁では現行の規制では複合臭等の悪臭 苦情への対応が困難な事, また臭いの苦情の大きな割 合をしめる日常生活に起因する悪臭に対応出来てない 事等より, 官能臭気による規制を検討中であり, 本年 中にも法制化する意向を示した。

環境庁が昭和 57 年に出した「官能試験法調査報告 書」にある「敷地境界線に於ける望ましい臭気濃度 (臭気指数)」の数値がそのまま適用された場合, 当業 界, 特にKP工場に於いては非常に厳しい対応を強 いられることが，各社官能臭気に係る実態調査結果よ $り$ 明確となった。現在 (平成 7 年 1 月), 製紙連合会 及び $\mathrm{KP}$ 製造主要メンバー会社を中心に，業界をあ げて行政側および各方面と折衝を進めている。

\section{4. 悪臭対策の実施状況}

排煙臭気対策，工程・建屋漏洩臭気对策，並びに， 臭気対策に係る操業管理方法, 現在の課題, 今後の対 応策について調査を行つた。各工場回答の解析結果を 下記に取りまとめる。

(1) 排煙臭気対策

排煙臭気对策としては, 低臭気型 RB の導入を挙げ ている工場が 29 工場と最も多い。次いで濃黑液酸化 の実施が 11 工場となっている。これは RB 排煙のア ルカリ洗浄 (2 工場) と共に従来型 RBの排煙臭気対 策と思われる。また，4工場が石灰キルンの排煙アル カリ洗浄を行っており，3 工場が RB ディゾルバー排 
表 3-1 KP 工場に係る官能臭気規制の実施状況

\begin{tabular}{|c|c|c|c|c|c|c|c|c|}
\hline \multirow{2}{*}{ 自治体 } & \multirow{2}{*}{$\begin{array}{c}\text { 規制の } \\
\text { 名称 }\end{array}$} & \multirow{2}{*}{$\begin{array}{l}\text { 施行 } \\
\text { 年月 }\end{array}$} & \multirow{2}{*}{ 測定法 } & \multicolumn{3}{|c|}{ 規制内容 } & \multirow{2}{*}{$\begin{array}{l}\text { 該当 } \\
\mathrm{KP} \\
\text { 工場数 }\end{array}$} & \multirow{2}{*}{ 措置等 } \\
\hline & & & & \multicolumn{2}{|c|}{ 規制対象 } & 規制基準 & & \\
\hline \multirow[t]{2}{*}{ 北海道 } & \multirow{2}{*}{$\begin{array}{l}\text { 悪臭対策 } \\
\text { 指導要綱 }\end{array}$} & \multirow[t]{2}{*}{ S 59.7} & \multirow{2}{*}{$\begin{array}{l}\text { 三点比較式 } \\
\text { 臭袋法 }\end{array}$} & \multicolumn{2}{|c|}{ 敷地境界線 } & 臭気指数 10 & \multirow[t]{2}{*}{7 工場 } & \multirow{2}{*}{$\begin{array}{l}\text { 改善措置の } \\
\text { 指導 }\end{array}$} \\
\hline & & & & 排出口 & $\begin{array}{l}\text { 回収ボイラ } \\
\text { 石炭キルン }\end{array}$ & $\begin{array}{ll}\text { 臭気指数 } & 30 \\
\text { 臭気指数 } & 30\end{array}$ & & \\
\hline 宮城県 & $\begin{array}{l}\text { 悪臭公害 } \\
\text { 防止对策 } \\
\text { 要綱 }\end{array}$ & S 53.4 & $\begin{array}{l}\text { 三点比較式 } \\
\text { 臭気採点法 }\end{array}$ & \multicolumn{2}{|c|}{ 敷地境界線 } & 臭気強度 $\quad 1.8$ & 2 工場 & 改善勧告 \\
\hline \multirow[t]{2}{*}{ 山口県 } & \multirow{2}{*}{$\begin{array}{l}\text { 悪臭防止 } \\
\text { 対策指導 } \\
\text { 要綱 }\end{array}$} & \multirow[t]{2}{*}{ S 58.6} & \multirow{2}{*}{$\begin{array}{l}\text { 三点比較式 } \\
\text { 臭袋法 }\end{array}$} & \multicolumn{2}{|c|}{ 敷地境界線 } & 臭気指数 & \multirow[t]{2}{*}{1 工場 } & \multirow{2}{*}{$\begin{array}{l}\text { 改善措置の } \\
\text { 勧告 }\end{array}$} \\
\hline & & & & \multicolumn{2}{|c|}{$\begin{array}{l}\text { 排出口高さ } 15 \mathrm{~m} \text { 以上 } 30 \mathrm{~m} \text { 末満 } \\
\text { 排出口高さ } 30 \mathrm{~m} \text { 以上 } 50 \mathrm{~m} \text { 末満 } \\
\text { 排出口高さ } 50 \mathrm{~m} \text { 以上 }\end{array}$} & $\begin{array}{ll}\text { 臭気指数 } & 32 \\
\text { 臭気指数 } & 34 \\
\text { 臭気指数 } & 37\end{array}$ & & \\
\hline \multirow[t]{2}{*}{ 岩手県 } & \multirow[t]{2}{*}{ 指導要領 } & \multirow[t]{2}{*}{ H 5.6} & \multirow{2}{*}{$\begin{array}{l}\text { 三点比較式 } \\
\text { 臭袋法 }\end{array}$} & \multicolumn{2}{|c|}{ 敷地境界線 } & 臭気濃度 10～30 & \multirow[t]{2}{*}{1 工場 } & \multirow[t]{2}{*}{ なし } \\
\hline & & & & 排出口 & $\begin{array}{l}\text { 最大着地濃 } \\
\text { 地点で測定 }\end{array}$ & $\begin{array}{l}\text { なる } \\
\text { な濃度 } 10 \text { - 30 }\end{array}$ & & \\
\hline \multirow[t]{2}{*}{ 八戸市 } & \multirow[t]{2}{*}{$\begin{array}{l}\text { 悪臭防止 } \\
\text { 指導要綱 }\end{array}$} & H 2.12 & $\begin{array}{l}\text { 三点比較式 } \\
\text { 臭袋法 }\end{array}$ & \multicolumn{2}{|c|}{ 敷地境界線 } & $\begin{array}{ll}\text { 臭気指数 } & 18 \\
\text { 臭気濃度 } & 60\end{array}$ & 1 工場 & $\begin{array}{l}\text { 改善勧告 } \Rightarrow \\
\text { 事実の公表 }\end{array}$ \\
\hline & & & & 排出口 & $\begin{array}{l}\text { 回収ボイラ } \\
\text { 石炭キルン }\end{array}$ & $\begin{array}{lr}\text { 臭気指数 } & 35 \\
\text { 臭気濃度 } 3,000 \\
\text { 臭気指数 } \\
\text { 臭気濃度 } 3,000\end{array}$ & & \\
\hline 富士市 & 悪臭公害 & S 55.10 & 三点比較式 & 敷地境 & & 臭気濃度 & 2 工場 & 改善勧告 $\Rightarrow$ \\
\hline & $\begin{array}{l}\text { 防止対策 } \\
\text { 指導要綱 }\end{array}$ & $\begin{array}{r}\mathrm{H} 1.4 \\
\text { 改正 }\end{array}$ & 臭袋法 & 排出口 & $\begin{array}{l}\text { 回収ボイラ } \\
\text { 石炭キルン } \\
\text { PS 焼却炉 }\end{array}$ & $\begin{array}{l}\text { 着地臭気濃度 } 10 \\
\text { 着地臭気濃度 } 10 \\
\text { 着地臭気濃度 } 10\end{array}$ & & 氏名の公表 \\
\hline 大竹市 & 悪臭公害 & H 5.5 & 三点比較式 & 敷地境 & & 臭気指数 & 2 工場 & 改善勧告 $\Rightarrow$ \\
\hline & $\begin{array}{l}\text { 防止対策 } \\
\text { 指導要綱 }\end{array}$ & & 臭袋法 & 排出口 & $\begin{array}{l}\text { 回収ボイラ } \\
\text { 石炭キルン } \\
\text { 污泥焼却炉 }\end{array}$ & $\begin{array}{l}\text { 臭気指数 } \\
\text { 臭気指数 } \\
\text { 臭気指数 }\end{array}$ & & 事実の公表 \\
\hline
\end{tabular}

気のアルカリ洗浄を行っている。これらは中所発生源 対策の必要性を示しているものと言える（表 4-1）。

(2) 工程・建屋の漏洩臭気対策

工程・建屋の漏洩臭気対策としては, 殆どの工場が 臭気排水のストリッピング処理と工程臭気ガスの捕 集・燃荠処理を採用している（表 4-2）。

(3) 臭気対策に係る操業管理

白液の硫化度管理と排煙の TRS 濃度管理を挙げた 工場が最も多かった。白液の硫化度管理は 21 工場で 行われており, 硫化度 28３0\%以下としてる工場が
多い。2工場が $27 \%$ 以下している。また，排煙の TRS 管理は 18 工場が行っており，管理指標の最大值 はTRS $20 \mathrm{ppm}$ 以下となっているが, 5 工場が 1 ppm 以下としている。また, 4 工場が濃黑液の $\mathrm{Na}_{2} \mathrm{~S}$ 濃度管理を行っており，その管理目標値は最大 0.5 $\mathrm{g} / \mathrm{l}$ 以下, 最小 $0.1 \mathrm{~g} / \mathrm{l}$ 以下になっている (表 4-3)。

\section{(4) 臭気对策に係る現在の課題}

臭気対策に係る現在の課題としては，活性污泥 (AS) 処理等の排水処理設備からの臭気対策を挙げる 工場が 12 工場と一番多い。臭気性排水処理対策や排 
表 3-2 官能試験法を採用している自治体

(平成 6 年 1 月現在, 環境庁)

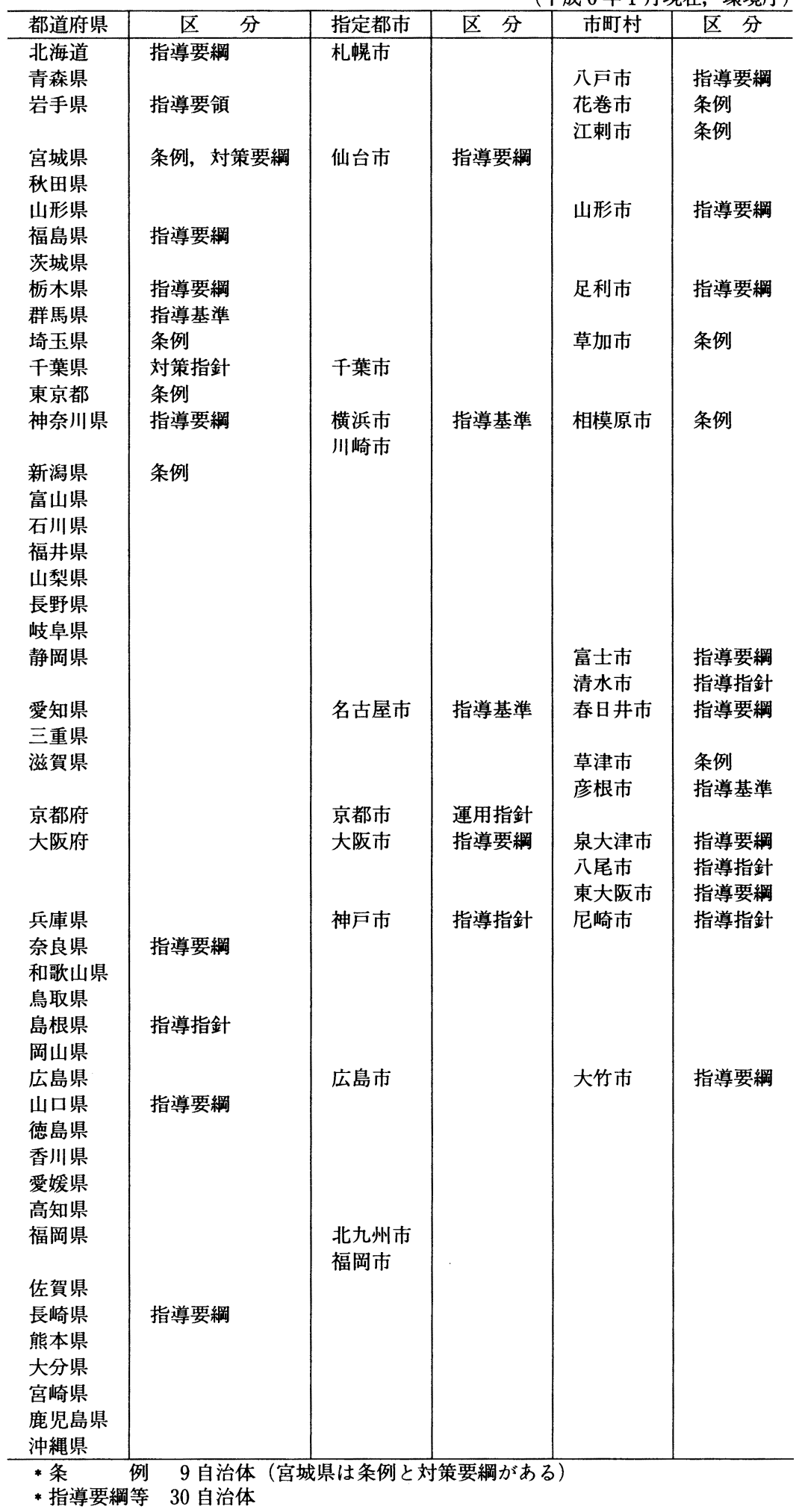


表 4-1 排煙臭気対策

\begin{tabular}{ll|c}
\hline \multicolumn{1}{c|}{ 対 策 項 目 } & 工場数 \\
\hline (1) & 低臭気型 $\mathrm{RB}$ の導入 & 29 \\
\hline (2) & 濃黒液酸化の実施 & 11 \\
\hline (3) & 石灰キルン排ガスのアルカリ洗浄 & 4 \\
\hline (4) & $\mathrm{RB}$ ディゾルバー排ガスのアルカリ洗浄 & 3 \\
\hline (5) & $\mathrm{RB}$ 排ガスのアルカリ洗浄 & 2 \\
\hline (6) & 高煙突の設置 & 2 \\
\hline (7) & 酸化塔排ガスの燃焼処理 & 1 \\
\hline (8) & RB 炉内監視テレビ設置 & 1 \\
\hline (9) & 石灰キルン負荷低減 & 1 \\
\hline
\end{tabular}

表 4-2 工程・建屋漏洩臭気対策

\begin{tabular}{ll|c}
\hline \multicolumn{1}{c|}{ 対 策 項 目 } & 工場数 \\
\hline (1) & 臭気排水ストリッピング処理 & 35 \\
\hline (2) 工程臭気ガスの捕集・燃焼処理 & 35 \\
\hline (3) 設備の密閉化 & 5 \\
\hline (4) 臭気ガスの高所排気 & 1 \\
\hline (5) 污泥発生排ガスのハイポ処理 & 1 \\
\hline (6) 臭気ガスの酸化吸収処理 & 1 \\
\hline
\end{tabular}

表 4-3 操業の中における管理方法

\begin{tabular}{|c|c|}
\hline 対 策 項 目 & 工場数 \\
\hline (1) 白液の硫化度管理 & 21 \\
\hline (2) 排煙の TRS 濃度管理 & 18 \\
\hline (3) 濃黒液の $\mathrm{Na}_{2} \mathrm{~S}$ 濃度管理 & 4 \\
\hline (4) スクラバー $\mathrm{pH}$ 管理 & 3 \\
\hline (5) 排ガスの残 $\mathrm{O}_{2}$ 濃度管理 & 3 \\
\hline (6) ストリッピング $\mathrm{pH}$ 管理 & 2 \\
\hline (7) 建屋内 $\mathrm{H}_{2} \mathrm{~S}$ 計設置 & 1 \\
\hline (8) ガスコンデンサー温度管理 & 1 \\
\hline
\end{tabular}

水処理工程での嫌気性発酵の抑制対策などが課題とも 言える。また，スラッジ焼却炉の排煙臭気対策と外材 チップの荷卸時の臭気対策がそれぞれ 1 工場から報告 されている(表 4-4)。

(5) 臭気対策に係る今後の対応；
表 4-4 臭気対策に係る現在の課題

\begin{tabular}{|c|c|c|}
\hline & 題 & 工場数 \\
\hline (1) & AS 等排水処理設備の臭気対策 & 12 \\
\hline (2) & 蒸解洗浄建屋の漏洩臭気対策 & 3 \\
\hline (3) & カスケードエバ排煙臭気対策 & 2 \\
\hline (4) & スラッジ焼却炉の排煙臭気対策 & 1 \\
\hline & 外材チップ荷卸時の臭気対策 & 1 \\
\hline & 排水路の臭気対策 & 1 \\
\hline & 定修時の配管臭気ドレン対策 & 1 \\
\hline (8) & $\mathrm{S} / \mathrm{C}$ の臭気負荷増加対策 & 1 \\
\hline
\end{tabular}

表 4-5 臭気对策に係る今後の対応策

\begin{tabular}{|c|c|}
\hline 検 討 項 目 & 工場数 \\
\hline (1) 新 RB の検討 & 2 \\
\hline (2) SD 後の立上げ時の対策 & 2 \\
\hline (3) KP, 酸素晒ブローガス燃焼 & 1 \\
\hline (4) パルプ工程統合 & 1 \\
\hline （5） S/Cに苛性ソーダ添加を検討 & 1 \\
\hline (6) ディゾルバー排ガス対策検討 & 1 \\
\hline （7） 臭気燃焼ラインの計装強化 & 1 \\
\hline （8） AS 密閉化 & 1 \\
\hline （9）ノッタ一等密閉化 & 1 \\
\hline (10) $\mathrm{E} / \mathrm{V}$ ドレン等のストリッピング & 1 \\
\hline (11) 余㮃污泥削減 & 1 \\
\hline (12) RB 空気吹込掃除口自動化 & 1 \\
\hline (13) RB 安定燃焼 & 1 \\
\hline (14) スラッジキルンの流動床ボイラ転換 & 1 \\
\hline
\end{tabular}

今後の臭気対策として検討の対象となる項目を表 4 -5 に示す。

\section{5. その他（地域の環境行政動向等）}

前述のように, 平成 5 年度に岩手県と大竹市が悪臭 公害防止対策指導要綱等を制定し，官能試験法による 規制を実施し，富士市が規制強化を予定している。ま た，排水の悪臭物質規制に関連して，6工場から自治 体等による排水臭気の测定が報告されている。 
《参考》

排出水中の悪臭物簤規制（3 号規制）について

排水中の悪臭物質規制は悪臭防止法施行以来 21 年 にして平成 6 年 4 月 21 日に公布されたが，当該政令 改定案は平成 5 年末に突然表面化し, 提案から非常に 短期間で決定されたものである。

この間 KP 製造主要会社をメンバーとした製紙連 合会臭気対策小委員会では，環境庁の提案内容の確認， 各社に於ける臭気発生・処理・排出実態の把握及び削 減対策の検討を進める一方，これ等の調查結果を基に して業界をあげて関係省庁及び各方面との折衝を進め た。その結果, 最終的に「政令の施行を平成 7 年 4 月 まで延期する事，及びそれ以降の 2 年間については改 善勧告の実施基準に制限を設ける」等により通算 3 年 間の猶予期間が認められる事となった。更に測定方法 についても業界で調査した結果，かなり慎重さを要求 されるものであり，法が施行されるまでに測定の詳細 なマニュアルを環境庁にて作成する事が約束された。

\section{[規制の概要]}

昭和 47 年の法の施行当時, 排水中の悪臭物質の濃 度と大気中に蒸散した当該悪臭物質の濃度との関係が 明確でなかった為，当分基準を定めない事とされてき た。今回，中環審では「悪臭物質の排出中の濃度と大 気中の濃度の関係を表す理論式の設定は無理」であり, 替わって「排水中とその直上の大気中とに於いて既に 実測値の得られている硫黄系 4 物質について, 排出中 の濃度と大気中の評価地点（人の鼻の高さとして地上 $1.5 \mathrm{~m})$ に於ける濃度の関係を実測から導き出す事が 現実的な方法である」との結論を出し，下記の関係式 を導き出している。

$$
\begin{aligned}
& \mathrm{C}_{\mathrm{Lm}}=\mathrm{k} * \mathrm{C}_{\mathrm{m}} \\
& \text { ただし, }
\end{aligned}
$$

$\mathrm{C}_{\mathrm{Lm}}$ ：排出水中の悪臭物質濃度の許容限度（単位： $\mathrm{mg} / l)$

$\mathrm{k}$ : 定数 (表 5-1のとおり, 単位 $: \mathrm{mg} / \mathrm{l}$ )

$\mathrm{C}_{\mathrm{m}}: 1$ 号規制で定められた事業場敷地境界線にお ける規制基準值 (単位：mg/l)

この中で, 種々の要因のうち特に排出水の水量の影 響が大きく，その他の要因は総合的に影響しているも のとして水量により 3 水準い分けた形をとっている (表 5-1，5-2 参照)。

悪臭物質の定量方法としては, ヘッドスペース法と ガスクロマトグラフの組合せが採用されており，この ヘッドスペース法については既に「JIS K 0125 揮発 性有機塩素化合物の測定方法」に採用されているもの と同様の原理に基づくものである。

尚, 今回対象となった悪臭物質は上述のとおり硫黄 系 4 物質だけであるが，その他の悪臭物質についても 今後追加指定される可能性が残されている。

表 5-1 定数 $\mathrm{k}$ の值

\begin{tabular}{c|c|c|c}
\hline \multirow{2}{*}{ 物 質 名 } & \multicolumn{3}{|c}{$\mathrm{k}$} \\
\cline { 2 - 4 } & $\mathrm{Q} \leqq 10^{-3}$ & $10^{-3}<\mathrm{Q} \leqq 10^{-1}$ & $10^{-1}<\mathrm{Q}$ \\
\hline メチルメルカプタン & 16 & 3.4 & 0.71 \\
硫 化 水 素 & 5.6 & 1.2 & 0.26 \\
硫化 チ & 32 & 6.9 & 1.4 \\
二硫化メチル & 63 & 14 & 2.9 \\
\hline
\end{tabular}

（注） $\mathrm{Q}\left(\right.$ 単位 $: \mathrm{m}^{3} / \mathrm{s}$ ) は事業場の敷地外に排出され る排出水の量を表わす

表 5-2 関係式から求めた排出水に係る規制基準值

(単位：mg/l)

\begin{tabular}{l|l|l|l|l|l|l|l|l|l}
\hline & \multicolumn{3}{|c|}{$\mathrm{Q} \leqq 10^{-3}$} & \multicolumn{3}{c|}{$10^{-3}<\mathrm{Q} \leqq 10^{-1}$} & \multicolumn{3}{c}{$10^{-1}<\mathrm{Q}$} \\
\hline 強度 & 2.5 & 3.0 & 3.5 & 2.5 & 3.0 & 3.5 & 2.5 & 3.0 & 3.5 \\
$\mathrm{H}_{2} \mathrm{~S}$ & 0.1 & 0.3 & 1 & 0.02 & 0.07 & 0.2 & 0.005 & 0.02 & 0.05 \\
$\mathrm{MM}$ & 0.03 & 0.06 & 0.2 & 0.007 & 0.01 & 0.03 & $* 0.001$ & 0.003 & 0.007 \\
DMS & 0.3 & 2 & 6 & 0.07 & 0.3 & 1 & 0.01 & 0.07 & 0.3 \\
DMDS & 0.6 & 2 & 6 & 0.1 & 0.4 & 1 & 0.03 & 0.09 & 0.3 \\
\hline
\end{tabular}

（注） 1. Q：排水量 $\left(\mathrm{m}^{3} / \mathrm{s}\right)$, 強度：臭気強度, $\mathrm{H}_{2} \mathrm{~S}$ ：硫化水素, $\mathrm{MM}$ : メチルメルカプタン, DMS：硫化メチル, DMDS：二硫化メチル

2.*印：測定条件から，規制基準值としては $0.002 \mathrm{mg} / l$ とする必要がある。 